IRA-International Journal of Management \& Social Sciences

ISSN 2455-2267; Vol.04, Issue 03 (2016)

Pg. no. 526-535

Institute of Research Advances

http://research-advances.org/index.php/RAJMSS

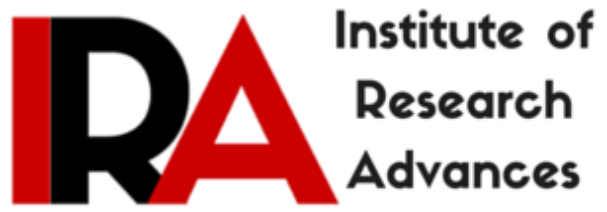

\title{
Theory A for Optimizing Human Productivity
}

\author{
${ }^{1}$ Dr. P. S. Aithal and ${ }^{2}$ Dr. Suresh Kumar P. M. \\ ${ }^{\mathbf{1 , 2}}$ Srinivas Institute of Management Studies, Pandeshwar, \\ Mangalore - 575 001, India.
}

Type of Review: Peer Reviewed.

DOI: http://dx.doi.org/10.21013/jmss.v4.n3.p2

\section{How to cite this paper:}

Aithal, P., \& Kumar P. M., S. (2016). Theory A for Optimizing Human Productivity. IRA-International Journal of Management \& Social Sciences (ISSN 2455-2267), 4(3), 526-535. doi:http://dx.doi.org/10.21013/jmss.v4.n3.p2

(C) Institute of Research Advances

\section{$(\mathrm{cc})$ EY-NC}

This work is licensed under a Creative Commons Attribution-Non Commercial 4.0 International License subject to proper citation to the publication source of the work.

Disclaimer: The scholarly papers as reviewed and published by the Institute of Research Advances (IRA) are the views and opinions of their respective authors and are not the views or opinions of the IRA. The IRA disclaims of any harm or loss caused due to the published content to any party. 


\begin{abstract}
Optimizing human productivity is a challenging process for the organizations and this process involves getting the best performance from employees within the organizational constraints. Even though the performance of human resources in organizations mainly depend on technology and external environment, ways of thinking individually and by teams, and humanistic orientation are important. Various models are used in developing a strategy to improve the people's performance in organizations. Such for example, are theory $X$, theory $Y$ and theory A. All these in common are based on presumptions about the human behaviour at work. Theory $X$ and $Y$ are opposing each other in predicting human nature. Theory $X$ describes human nature as lazy, dislikes work and avoids, lacks responsibility, seeks security, lack of ambition and therefore should be forced, controlled, threatened or closely supervised to get work. Theory $Y$ believes in the exercise of self-direction and self-control investing faith in individual potential, imagination, creativity and its application to work. Against this is theory A which focuses innate human potential, inherent urge for creativity, self-expression and contribution to the organization as motivators. As such, managers have to transform average employee to real performers using role models and self-exploration. This paper attempts to compare factors affecting organizational performance in all these aforesaid theories. It also details a set of model operational steps in introducing the theory of accountability. It also makes a SWOC analysis of theory A and its application to different types of organizations.
\end{abstract}

Keywords: Theory A, Optimizing human productivity, Organizational success, SWOC analysis.

\title{
1. Introduction
}

Optimizing Human Productivity (OHP) is a challenging process for the organization, and this process involves getting the best performance from employees within the organizational constraints. Optimizing Human Performance is used in all business functions to improve individual and group output, reliability, and productivity. Employee growth and development towards higher levels of competency, creativity and fulfilment are encouraged and supported because people are the central resource in any organization. The most successful optimizing human productivity models have five key elements [1]. When implemented properly these elements enable organizations to thrive through the engagement of their employees. The important elements for OHP include (1) Leadership Commitment, (2) Human Capital Planning, (3) Attracting, Developing, and Retaining Employees, (4) Communications Strategy, and (5) Impact Metrics. Optimization involves designing a system or process to perform as well as possible. Even though the performance of human resources in organizations mainly depends on the technology and External environment which substantially impacts organizational behaviour, the way of thinking individually and by teams, and humanistic orientation, which assumes that individual feelings, attitudes, perceptions, goals, etc., are important to the organization. Many researchers have tried to optimize productivity using different strategies [2-4] including motivation of employees [5], privatization of organizations [6], optimizing risks and optimizing rewards [7] etc. and its measurement [8].

Various models are used in planning to frame a strategy to improve the performance of people in organizations. It is also important for the managers to recognize the nature, significance and effectiveness of their organizations model as well as the models of others around them while planning their strategy to improve the employee performance. Out of such models, Theory X, Theory Y, and recently introduced Theory A are significant in deciding the productivity [9 -10]. As per theory $\mathrm{X}$ model, a typical person dislikes work and avoids it if possible. The typical person lacks responsibility, has little ambition and seeks security above all. Most people must be coerced, controlled, and threatened with punishment to get them to work. With these assumptions, the managerial role is to coerce and control employees. As per theory Y model, work is as natural as play or rest. People are not inherently lazy. They have become that way as a result of experience. People will exercise self-direction and self-control in the service of the 
objectives to which they are committed. People have potential. Under proper conditions, they learn to accept and seek responsibility. They have imagination, ingenuity, and creativity that can be applied to work. With these assumptions, the managerial role is to develop the potential in employees and help them release that potential toward common objectives.

\section{Theory A for Optimizing Human Productivity :}

According to Theory A or Theory of Accountability, a proper strategy should be planned in the organization depending on its objectives and set target. Accountability should be fixed to both individuals and teams in order to ensure success in given task. The functional elements of Accountability Theory (Theory A) are [10-11] :

(1) Planning - Institutional assessment, problem identification, and joint policy formulation.

(2) Target setting - Communication, shared understanding, and action planning.

(3) Motivation - Adoption of the idea and increased performance.

(4) Work Strategies - Empowerment, support and team-work.

(5) Responsibility - Commitment, consistency, and target fulfillment.

(6) Role model - Following example and willingness to improve.

(7) Monitoring \& Guiding - Joint review, self-appraisal, and confirmation of accomplishment.

(8) Accountability - Contribution through commitment and creativity.

Based on Focus group method and its effective usage in different research model proposals, [12- 26], a set of postulates have been developed to model theory A [10]. These postulates of theory A connect the following factors of organizational performance.

(i) Identify and prioritize relevant Objective.

(ii) Set individual and team Targets through planning.

(iii) Bring Responsibility in each member of the team/organization.

(iv) Prove the expected result through Role Model.

(v) Monitor the performance continuously.

(vi) Fix Accountability for both winners and losers.

(vii) Goal attainment.

The various steps of theory A are discussed below [27] :

(1) Planning :

Either individually or jointly head of the organization reflects on the institutional strength and weaknesses. This is a periodic function to keep the relevance of the organization updated and face newer challenges that emerge. As a consequence, various problems may surface, but using ingenuity and discretion, the pressing problem is zeroed in. This is collectively done. A candid policy is essential for backing managerial actions. This is formulated involving section heads. The policy spells out in clear terms the broad direction the organization will be heading for.

\section{(2) Target Setting :}

The problem that has been identified and the policy formulated have to be communicated to everyone in the organization. This stimulates a process of mutual consultation and dialogue among members of the organization. As a result, the members realize what has been ailing them and how to overcome that. They become prepared to devote their effort towards better performance.

\section{(3) Motivation :}

Following the realization and preparedness to perform desirably, their interest is aroused through group process by which the group adopts the idea. This group process also helps members discover their potential through self-exploration. They are also influenced by their reference group namely ideal 
performers. Ideal performers are hypothetical performers having characteristics like ideal systems [2833]. As a result of this ideas become translated into performance.

\section{(4) Work Strategies :}

Strategy is important for success. First and foremost, it is important that the members of the organizations set their individual goals in consonance with the organizational goal. This comes in the form of a desire. Identical goals transform into sharing of group goals and generate team spirit. Materialising creative talents give the individual a feeling of empowerment. The organization also extends support as the enabling strategy.

\section{(5) Responsibility :}

Assuming responsibility is owning responsibility, rather the manifestation of commitment. This gives speed and certainty of actions in delivering responsibility. Then comes task execution which is a crucial part of all. This is done for goal attainment that helps target fulfillment.

\section{(6) Role model :}

Good performance is highlighted. Best performers become role models which influence other members in performance. This results in the change of attitude from somewhat positive to highly positive for the mediocre performers and develops readiness to change.

\section{(7) Monitoring :}

There would be periodic revisits to the targets set, its execution and lag if any. This gives an opportunity for everyone to appraise their work/actions/task. As a consequence, the time frame is set for the lag. Members accomplish the task.

\section{(8) Accountability :}

Individual commitment is evaluated during performance assessment. Performance is measured against group goal, individual goal, and organizational support. That organization influence application of knowledge and skill into effective performance is reiterated. Performance is enhanced in a conducive environment of expediency created by necessity. Organization strives to foster inherent creativity to transform it and integrate it into the organizational goal. Acknowledgment of contribution is shared between individual and organization. Poor performers undergo recycling.

Table 1 : Affecting factors in organizational performance based on Theory X, Theory Y, and Theory A.

\begin{tabular}{|c|c|c|c|}
\hline S.No. & Theory A & Theory X & Theory Y \\
\hline 1 & Identify objective & Impose Objective & Establish objective \\
\hline 2 & Set Target & Fix target & Develop target \\
\hline 3 & Bring Responsibility & Exert strong direction & Apply motivation \\
\hline 4 & Prove through Role Model & $\begin{array}{c}\text { Attain through reward and } \\
\text { punishment }\end{array}$ & $\begin{array}{c}\text { Promote through } \\
\text { encouragement }\end{array}$ \\
\hline 5 & Monitor continuously & Look for control & Self Control \\
\hline 6 & Set Accountability & Resort to compulsion & Rising expectation \\
\hline 7 & Goal attainment & Realization of output & Materialising outcome \\
\hline
\end{tabular}

\section{Effect of Theory A on Organizational Productivity}

(1) Knowledge and skill can be enhanced in a congenial environment where the organization can exert a positive impact. Congenial environment is where employees feel that they are involved and their participation is fostered through joint problem identification, policy formulation, target setting, action planning, adopting work strategy, responsibility, and accountability. 
(2) Organization influences the application of knowledge and skill into practice. Similar to the above, the application of knowledge and skill is also depending largely on the organization. An organization might have plenty of talents in its human resource, but how they apply it for the sake of the organization is what counts in productivity.

(3) Organizations which believe in participating the employee through fixing targets jointly finds that compliance is out of goodwill and share an increased sense of responsibility.

\subsection{How Theory A supports to achieve Organizational Objectives :}

(1) When individual life goals are integrated with the organizational goal, organizational objectives take precedence. The individual perceive his identity in the organization with the result that contributing to the organization gives him satisfaction.

(2) Channelling creativity into work effort leads to the efficiency of the organization. It is important that employees become aware of their potential and inherent creativity. Self-exploration and following role models will serve this.

(3) Manager acts as leader and employee are involved in problem identification, target setting, implementation, and evaluation. Through performing, improving and contributing the employee fulfill target and manifest accountability.

\subsection{Factors affecting the organizational productivity as per theory $A$.}

(1) Creativity and contribution to the organization act as a prime motivator.

(2) Acknowledgment of a creative potential of every employee brings self fulfilment.

(3) Responsibility is reckoned as fulfilment of target.

\subsection{Effect of Theory A on Human Productivity :}

(1) Belief in the potential of each employee is at the root of this theory.

(2) Average employee can be transformed into real performer through identification of role models and self exploration.

(3) Rewards, more importantly are feeling of creativity and contribution to the organization.

\subsection{Theory A and Long- term Sustainability :}

Any organization which believes that competent employees can make things happen strives to channel their creativity towards organizational productivity. Motivation and monitoring are the key instruments which sustain the results. Managerial leadership becomes important here. An organization which follows theory A philosophy would need a managerial style that demands the twin elements of leader and follower combined in one. The manager should not lead from the distance but follow his men together.

\section{Theory A applied to different Organizations}

The description below refers to ideal characteristics with regard to five types of institutions which have been taken here for comparison, in theory A framework as shown in table 2.

Table 2 : Theory A applied to different Organizations.

\begin{tabular}{|l|l|l|l|l|l|l|}
\hline $\begin{array}{l}\text { S. } \\
\text { No. }\end{array}$ & Theory A Stages & $\begin{array}{l}\text { Performing } \\
\text { Indicators }\end{array}$ & $\begin{array}{l}\text { Public } \\
\text { Sector }\end{array}$ & $\begin{array}{l}\text { Military } \\
\text { Organization }\end{array}$ & NGO & $\begin{array}{l}\text { Educational } \\
\text { Institutions }\end{array}$ \\
\hline 1 & Planning & Power & Segregated & $\begin{array}{l}\text { Concentration } \\
\text { of power }\end{array}$ & $\begin{array}{l}\text { Largely } \\
\text { diffused }\end{array}$ & $\begin{array}{l}\text { Power does } \\
\text { not interfere } \\
\text { in } \\
\text { performance }\end{array}$ \\
\hline 2 & Target setting & Task & Stereotype & Routine & $\begin{array}{l}\text { Maintain } \\
\text { low spirits }\end{array}$ & $\begin{array}{l}\text { Scope for } \\
\text { creativity }\end{array}$ \\
\hline
\end{tabular}




\begin{tabular}{|l|l|l|l|l|l|l|}
\hline 3 & Motivation & $\begin{array}{l}\text { Employee } \\
\text { profile }\end{array}$ & Lethargic & Charged & Medium & Pro-active \\
\hline 4 & Work strategy & $\begin{array}{l}\text { Nature of } \\
\text { management }\end{array}$ & $\begin{array}{l}\text { Laissez- } \\
\text { faire }\end{array}$ & Authoritarian & Collective & Democratic \\
\hline 5 & Responsibility & $\begin{array}{l}\text { Execution } \\
\text { of work }\end{array}$ & $\begin{array}{l}\text { Pass the } \\
\text { buck }\end{array}$ & $\begin{array}{l}\text { Bound to } \\
\text { deliver }\end{array}$ & Distributive & Adaptive \\
\hline 6 & Role model & Example & None & Superior & Founder & Leader \\
\hline 7 & Monitoring & $\begin{array}{l}\text { Putting in } \\
\text { frame }\end{array}$ & Feedback & $\begin{array}{l}\text { Strong } \\
\text { control }\end{array}$ & $\begin{array}{l}\text { Network } \\
\text { operation }\end{array}$ & Dialogue \\
\hline 8 & Accountability & Result & $\begin{array}{l}\text { Limited to } \\
\text { few }\end{array}$ & Compulsory & Part of work & $\begin{array}{l}\text { Depends on } \\
\text { set standards }\end{array}$ \\
\hline
\end{tabular}

\subsection{Public Sector Organizations :}

When power is concentrated at higher levels and unwilling to be shared, planning process involving the employees becomes difficult. In public sector organizations, power is largely segregated. No one has absolute power over anything and all what is supposed to be within the powers is subject to checks. The task to be performed is a stereotype, posing no feeling of challenge. Both these groom the employees to be sort of lethargic. There is hardly any application of strategy and employees pass the buck instead of holding themselves responsible. There is no example to follow and monitoring is confined to feedback. Accountability is limited to a few. With all these characteristics of performing indicators, theory A brings out the tales of poor performance of the public sector.

\subsection{Military Organizations :}

Military organizations are characterized by a higher concentration of power systematically delegated to lower levels in a way that planning becomes minimized towards lower levels and implementation becomes mostly the concern. The vast majority of rank and files are left to follow orders and not involve in planning their task. Hence the task becomes routine. Yet everyone in the organization remains charged since motivation is on life and death. The management style is clearly authoritarian and execution of work carries bound to deliver the directions. The superior is the role model to be copied and strong control is exercised in monitoring. The result is compulsory as the orders are binding without consultation or choice. Theory A implementation framework reveals the disciplined and demanding management characteristic of a military organization.

\subsection{NGOs :}

Non-governmental organizations (NGOs) are largely diffused when it comes to the planning of activities. Influenced by the mission of humanitarian service and relief, NGOs display low spirits in setting targets and a medium level of motivation. They are not vigorous or ambitious but sober and persevere. The NGOs involve all their employees in developing strategies since the reality to tackle is at grassroots. For the NGO the founder is the role model. The NGO personnel are mutually interconnected and they monitor through network operation. Accountability is an everyday affair and part of their work.

\subsection{Educational Institutions :}

Educational institutions offer huge potential for creativity and contribution and power does not interfere with the planning for performance. Their task has vast scope for creativity. Mostly proactive to motivation, they evolve work strategies democratically. In the execution of work they own responsibility more voluntarily. Their work is put in the frame through monitoring by dialogue. For them, the leader who influences them becomes a role model and accountability can be improved through setting standards. 


\section{SWOC Analysis of Theory A}

Identifying the strength, weakness, opportunities, and challenges of a theory or an organization or an individual in a framework popularly known as SWOC analysis has been developed in the last century [22]. Recently another analysing technique has been developed to analyse any innovative concept, idea, model, strategy, or system called ABCD analysis technique. The acronym ABCD stands for Advantages, Benefits, Constraints, and Disadvantages. [34-43]. The ABCD listing on theory A has been attempted earlier [10] and in this discussion, we have used SWOC analysis for the qualitative listing of strength, weakness, opportunities, and challenges of theory A.

\subsection{Strength of Theory A :}

(1) Invest faith in the inherent potential of every employee and opportunity to develop the capability.

(2) Money and position are not essential rewards to raise productive efficiency.

(3) This style of management raises team spirit to high levels.

(4) Employees will contribute to the organization if his creativity is accepted.

(5) Individual objective and organizational objective could become one at the same.

\subsection{Weakness of Theory A :}

(1) Target setting would be a difficult process for some.

(2) All employees may not assume responsibility easily.

(3) Some individuals fail to be motivated by creativity.

(4) Results may be slow in forthcoming.

(5) Demands committed leaders as managers.

\subsection{Opportunities of Theory A :}

(1) Changing outlook of the modern workforce.

(2) Changing perspectives of employers.

(3) Changing the style of management.

(4) Democratic expectations of labour unions.

(5) Newer forms of governance.

\subsection{Challenges of Theory $A$ :}

(1) There may be hesitation in accepting theory A as a basic philosophy for motivation and management.

(2) Not all organizations have strong and committed leadership.

(3) Sustainability of results for the long term is a challenge.

(4) Some individuals may be pessimistic about their own potential.

(5) Jealousy towards role models may hamper positive spirit.

\section{Conclusion}

Human productivity in organizations depends mainly on how efficiently the workers are managed. Despite the broad organizational objectives, each individual employee's objective- in performance terms 'target' - may become the organizational objective if it is identified through a collective planning process involving the employees and prioritization of needs depending on perceived problems. Motivation, then is adoption of the idea not through mere rewards or punishment but bringing in responsibility by helping in identifying creativity and transforming it into performance. This is at the bottom of Theory of Accountability. It is different from Theory $\mathrm{X}$ and $\mathrm{Y}$ in the sense that it is not imposing objectives or handing over an objective. However, the application of Theory A on various types of organizations requires to be viewed in terms of the rigidity and power structure of the organization. Rigidity pertains to task, its execution, example, and result whereas power structure includes employee profile, nature of management, and putting the performance in frame. Theory $\mathrm{A}$ is in tune with the changing outlook of 
modern workforce, changing perspectives of employer, changing style of management, democratic expectations of labour unions and a test for newer forms of governance.

\section{References}

[1] Baron, Robert A., and Greenberg, Jerald. (2008). Behavior in organizations - 9th edition. Pearson Education Inc., New Jersey: p.248.

[2] Guest, D. E. (1997). Human resource management and performance: a review and research agenda. International journal of human resource management, 8(3), 263-276.

[3] Sandberg, J. (2000). Understanding human competence at work: an interpretative approach. Academy of management journal, 43(1), 9-25.

[4] Lazear, E. P., \& Shaw, K. L. (2007). Personnel economics: The economist's view of human resources. The Journal of Economic Perspectives, 21(4), 91-114.

[5] Puckett, R. P. (1981). Optimizing employee productivity through motivation. Foodservice Research International, 1(3), pp. 205-219, 1981.

[6] Johnston, R. V. (1996). Optimizing productivity through privatization and entrepreneurial management. Policy Studies Journal, 24(3), 444-463.

[7] Cascio, W., \& Boudreau, J. (2014). HR strategy: optimizing risks, optimizing rewards. Journal of Organizational Effectiveness: People and Performance, 1(1), 77-97.

[8] Ramlall, S. J. (2003). Measuring human resource management's effectiveness in improving performance. People and Strategy, 26(1), 51.

[9] McGregor, D. M. (1960). The human side of enterprise. New York: McGraw-Hill.

[10] Aithal, P. S., \& Suresh Kumar, P. M. (2016). Organizational Behaviour in $21^{\text {st }}$ Century - Theory A for Managing People for Performance. IOSR Journal of Business and Management (IOSR-JBM), 18(7), 126-134. DOI: $10.9790 / 487 \mathrm{X}-180704126134$.

[11] Aithal, P. S. (2016). How to Increase Research Productivity in Higher Educational Institutions SIMS Model. International Journal of Scientific Research and Modern Education (IJSRME), 1(1), 447458.

[12] Rogers, E.M., (1995). Diffusion of Innovation, The Free Press, NY.

[13] Aithal, P. S., \& Varambally, K .V. M. (2006). Security Issues in Online Financial Transactions with Special Reference to Banking Industry. Quality in Service Sector and Managerial Challenges - Allied Publisher Pvt. Ltd., 103-114, ISBN:81-7764-992-2,.

[14] Varambally, K. V. M., \& Aithal, P. S. (2009). Technological Management and Mobile Business Services in India - A Futuristic Approach, Proceedings on MIDISA - SAARC Conference on Change and Continuity : Management Prospects and Challenges, RIM, Thimphu, Bhutan, 121-139.

[15] Varambally, K. V. M., \& Aithal, P. S. (2009). Mobile Business Technology and Business Proliferation of Banks - A futuristic Approach, Amity Business Review - an Indian Journal, 10(1), 9 - 25.

[16] Aithal, P. S., \& Shubhrajyotsna Aithal, (2015). Ideal Technology Concept \& its Realization Opportunity using Nanotechnology. International Journal of Application or Innovation in Engineering \& Management (IJAIEM), 4(2), 153 -164.

[17] Aithal, P. S., \& Shubhrajyotsna Aithal, (2015). Managing Anticipated Breakthrough Technologies of 21st Century - A Review. International Journal of Research \& Development in Technology and Management Sciences, 21(6), 112-133. 
[18] Aithal, P. S. (2015). Concept of Ideal Business \& Its Realization Using E-Business Model. International Journal of Science and Research (IJSR), 4(3), 1267-1274.

[19] Aithal, P. S., \& Shubhrajyotsna Aithal. (2015). An Innovative Education Model to realize Ideal Education System. International Journal of Scientific Research and Management (IJSRM), 3(3), 24642469.

[20] Reshma, Aithal, P. S., Shailashree, V. T., \& Sridhar Acharya, P. (2015). An Empirical study on working from home - A popular E-business model. International Journal of Advance and Innovative Research, 2(2), 12-18.

[21] Reshma, Aithal, P. S., \& Sridhar Acharya, P. (2015). Relevance of On-line Office Administration through Working from Home in Future Education System, International Journal of Application or Innovation in Engineering \& Management, 4(4), 44-53.

[22] Aithal, P. S., \& Suresh Kumar, P. M., (2015). Applying SWOC Analysis to an Institution of Higher Education. International Journal of Management, IT and Engineering (IJMIE), 5(7), 231-247.

[23] Aithal, P.S., \& Suresh Kumar, P.M. (2015). Black Ocean Strategy - A Probe into a New type of Strategy used for Organizational Success, GE International Journal of Management Research, 3(8), 4565.

[24] Aithal, P. S., Shailashree, V. T., \& Suresh Kumar, P. M., (2015). Application of ABCD Analysis Model for Black Ocean Strategy. International Journal of Applied Research (IJAR), 1(10), 331-337.

[25] Aithal, P. S., Shailashree, V. T., \& Suresh Kumar, P. M. (2016). ABCD analysis of Stage Model in Higher Education. International Journal of Management, IT and Engineering (IJMIE), 6(1), 11-24.

[26] Aithal, P. S. (2016). Study on ABCD Analysis Technique for Business Models, Business strategies, Operating Concepts \& Business Systems. International Journal in Management and Social Science, 4(1), 98-115.

[27] Aithal, P. S., \& Suresh Kumar, P. M. (2016). Comparative Analysis of Theory X, Theory Y, Theory $\mathrm{Z}$, and Theory A for Managing People and Performance. International Journal of Scientific Research and Modern Education (IJSRME), I(1), 803-812.

[28] Aithal, P. S. (2015). Mobile Business as an Optimum Model for Ideal Business. International Journal of Management, IT and Engineering (IJMIE), 5(7), 146-159.

[29] Aithal, P. S., \& Shubhrajyotsna Aithal, (2014). Ideal education system and its realization through online education model using mobile devices, Proceedings of IISRO Multi Conference 2014, Bangkok, 140-146. ISBN No. 978-81-927104-33-13.

[30] Aithal, P. S. (2016). The concept of Ideal Strategy \& its realization using White Ocean Mixed Strategy. International Journal of Management Sciences and Business Research (IJMSBR), 5(4), 171179.

[31] Sridhar Acharya, P., \& Aithal, P. S. (2016). Concepts of Ideal Electric Energy System FOR production, distribution and utilization. International Journal of Management, IT and Engineering (IJMIE), 6(1), 367-379.

[32] Aithal. P. S. (2016). Concept of Ideal Banking and Realization of it using Ubiquitous Banking, Proceedings of National Conference on Changing Perspectives of Management, IT, and Social Sciences in Contemporary Environment, Manegma 2016, India. 13-24. ISBN 978-93-5265-6523.

[33] Aithal, P. S., \& Vaikuth Pai T., (2016). Concept of Ideal Software and its Realization Scenarios. International Journal of Scientific Research and Modern Education (IJSRME), I(1), 826-837. 
[34] Aithal, P. S., \& Suresh Kumar, P.M., (2016). Opportunities and Challenges for Private Universities in India. International Journal of Management, IT and Engineering (IJMIE), 6(1), 88-113.

[35] Aithal, P. S., and Shubhrajyotsna Aithal, (2016). Impact of On-line Education on Higher Education System. International Journal of Engineering Research and Modern Education (IJERME), I(1), 225-235.

[36] Padmanabha Shenoy, \& Aithal, P. S. (2016). A Study on History of Paper and possible Paper Free World. International Journal of Management, IT and Engineering (IJMIE), 6(1), 337-355.

[37] Aithal, P.S. (2015). Comparative Study on MBA Programmes in Private \& Public Universities - A case study of MBA programme plan of Srinivas University. International Journal of Management Sciences and Business Research (IJMSBR),. 4(12), 106-122.

[38] Aithal, P. S., and Suresh Kumar, P. M., Analysis of Choice Based Credit System in Higher Education. International Journal of Engineering Research and Modern Education (IJERME), 1(1), 278284.

[39] Varun Shenoy, \& Aithal, P. S. (2016). Changing Approaches in Campus Placements - A new futuristic Model. International Journal of Scientific Research and Modern Education (IJSRME), 1(1), 766-776.

[40] Aithal, P. S., Shailashree, V. T., \& Suresh Kumar, P. M. (2015). A New ABCD Technique to Analyze Business Models \& Concepts. International Journal of Management, IT and Engineering (IJMIE), 5(4), 409-423.

[41] Aithal P. S., Shailashree V.T., \& Suresh Kumar P. M., Analysis of NAAC Accreditation System using ABCD framework, International Journal of Management, IT and Engineering (IJMIE), Vol. 6, Issue 1, pp. 30 - 44, January 2016.

[42] Aithal, P. S., Shailashree, V. T., \& Suresh Kumar, P. M. (2016). Application of ABCD Analysis Framework on Private University System in India. International Journal of Management Sciences and Business Research (IJMSBR), 5(4), 159-170.

[43] Aithal, P. S., Shailashree, V. T., \& Suresh Kumar, P. M. (2016). The Study of New National Institutional Ranking System using ABCD Framework. International Journal of Current Research and Modern Education (IJCRME), 1(1), 389-402. 